\title{
PENAMBAHAN TEPUNG SERANGGA PADA MEDIA PERBANYAKAN Metarhizium sp. UNTUK MENINGKATKAN VIRULENSINYA TERHADAP HAMA BELALANG PADI PANDANWANGI
}

\author{
Oleh : \\ Ramli**) \\ Seftyan Tri Rahmat Kusnara*)
}

\begin{abstract}
Abstrak
Padi Pandanwangi merupakan padi lokal khas Cianjur yang hanya dapat tumbuh optimal di beberapa kecamatan di Kabupaten Cianjur. Belalang kembara (Locusta migratoria) merupakan hama yang paling sering menimbulkan kerusakan berat pada tanaman padi, mulai pada saat di persemaian, fase anakan, fase berbunga maupun fase berbuah. Pemanfaatan cendawan entomopatogen berpotensi untuk mengendalikan hama belalang. Salah satu jenis cendawan entomopatogen tersebut adalah Metarbizium sp. efektif membunuh serangga hama. Penelitian ini dilaksanakan pada bulan Maret-April 2019, menggunakan Rancangan Acak Lengkap yang terdiri dari 3 perlakuan dan 5 ulangan, yaitu P1 (Tepung jagung 100 gram+tepung jangkrik 15\%), P2 (Tepung jagung 100 gram+tepung kroto 15\%), dan P3 sebagai kontrol (Tepung jagung 100 gram). Hasil pengamatan menunjukkan bahwa mortalitas belalang kembara terbaik yaitu pada perlakuan 1 dengan rerata mortalitas $67 \%$ pada 72 jam dan $33 \%$ pada 84 jam. Hasil analisis $\mathrm{LT}_{50}$ menunjukkan bahwa perlakuan 1 dengan jumlah konidia $5.2 \times 10^{6}$ mempunyai nilai $\mathrm{LT}_{50}$ pada $72 \mathrm{jam}$ dan perlakuan 2 dengan jumlah konidia $4.7 \times 10^{6}$, mempunyai nilai $\mathrm{LT}_{50}$ pada 72 jam, sedangkan perlakuan 3 dengan jumlah konidia 4,35 x $10^{6}$ mempunyai $\mathrm{LT}_{50}$ pada 108 jam. Penambahan tepung serangga pada media biakan dapat merangsang cendawan entomopatogen menghasilkan enzim khitinase yang mampu mendegradasi khitin pada kutikula belalang kembara.
\end{abstract}

Kata kunci: Padi Pandanwangi, Metarbizium sp., Tepung Serangga, Mortalitas, LT $_{50 .}$

\begin{abstract}
Pandanwangi Rice is a local rice of Cianjur which can only grow optimally in several sub-districts in Cianjur Regency. The wandering grasshopper (Locusta migratoria) is a pest that most often causes severe damage to rice plants, starting at the nursery phase, the tillering phase, the flowering phase and the fruiting phase. The use of entomopathogenic fungi is very potential to be developed to control locust pests. One type of entomopathogenic fungus is Metarbizium sp. which is known effective in killing insect pests. This research was conducted in March-April 2019, using a completely randomized design consisting of 3 treatments and 5 replications, namely P1 (100 gram com flour $+15 \%$ cricket flour), P2 (100 gram corn flour $+15 \%$ crotoch flour) ), and P3 as controls (100 gram corn flour). The results of the observation showed that the best wandering grasshopper mortality was in treatment 1 with a mortality rate $67 \%$ at 72 hours and $33 \%$ at 84 hours. Test results of the $L_{50}$ analysis showed that the time needed to control $50 \%$ of Locusta migratoria on treatment 1 with the number of conidia $5.2 \times 10^{6}$ showed $L T_{50}$ at 72 hours and treatment 2 with the number of conidia $4.7 \times 10^{6}$ showed $L T_{50}$ at 72 bours, while treatment 3 with the number of conidia 4,35 $\times 10^{6}$ showed $L_{50}$ at 108 hours. Addition of insect flour on culture media can stimulate the
\end{abstract}


entomopathogenic fungus to produce the enzyme chitinase which is able to degrade chitin in the cuticle of the wandering locust.

Keywords: Pandanwangi Rice, Metarbizium sp., Insect Flour, Mortality, $L_{50 .}$

*) Alumni Fakultas Sains Terapan UNSUR

**) Dosen Fakultas Sains Terapan UNSUR 


\section{PENDAHULUAN}

Tanaman padi merupakan salah satu tanaman pangan utama di Indonesia karena lebih dari setengah penduduk Indonesia menjadikan beras sebagai sumber kebutuhan makanan pokok. Padi pandanwangi adalah salah satu varietas lokal atau khas Cianjur dengan tergolong padi bulu (javanica) yang tumbuh dan berkembang di Cianjur. Beras Pandanwangi Cianjur (Aromatic rice) merupakan salah satu jenis beras kualitas premium dan komoditas unggulan Kabupaten Cianjur. Padi Pandanwangi mulai berkembang di Kabupaten Cianjur pada tahun 1970. Penyebaran padi Pandanwangi di Cianjur mulai berkembang dari Kecamatan Warungkondang ke 6 Kecamatan lain di Wilayah Kabupaten Cianjur, seperti Kecamatan Cugenang, Kecamatan Cianjur, Kecamatan Cilaku, Kecamatan Cibeber, Kecamatan Cempaka dan Kecamatan Gekbrong (MP3C, 2015). Sekarang daerah tersebut menjadi daerah sentra pelestarian dan pengembangan produksi padi Pandanwangi.

Terdapat beberapa jenis hama tanaman padi Pandanwangi, seperti hama wereng hijau yang menyebabkan penyakit tungro, walang sangit, kepinding tanah dan wereng coklat. Wereng coklat sudah menyerang tanaman padi di Indonesia sejak pertengahan tahun 1970-an, selain dari pada wereng coklat (Sembiring, 2013), ada pula hama yang paling sering menimbulkan kerusakan berat hingga mengalami kerusakan total atau gagal panen yaitu hama belalang, hama ini menyerang tanaman padi pada saat di persemaian, fase anakan, fase berbunga maupun fase berbuah (Pamili, 2014).

$$
\text { Belalang kembara (Locusta }
$$

migratoria) merupakan hama tanaman padi di Indonesia, belalang biasanya merusak tanaman dari jenis rerumputan (grasses) seperti padi, jagung, palem, pisang, tebu, sereh, dan bambu. Tanaman yang terserang daunnya akan terpotong dan tinggi tulang daunnya. Keberadaan belalang biasanya dalam jumlah kecil yang disebut fase solitaria, sehingga tidak menimbulkan kerusakan. Apabila kelompok-kelompok tersebut bergabung menjadi rombongan besar, maka terjadi migrasi besar-besaran dan bergerak sangat jauh disebut fase gregarius. Pada fase inilah kerusakan berat pada tanaman pertanian terjadi dan masalah menjadi sangat berbahaya apabila migrasi terjadi ke daerah pertanian tanaman pangan seperti area padi dan palawija (Kartohardjono et al., 2009).

Selama ini, upaya pengendalian hama masih mengandalkan penggunaan insektisida sintetik. Selain itu petani pun menggunakannya melebihi dosis anjuran dan dilakukan secara terus menerus, sehingga dampaknya dapat mengganggu ekosistem dan kesehatan manusia. Penggunaan insektisida yang tidak sesuai dengan dosis maka akan mengganggu keseimbangan musuh alami, menyebabkan resurjensi atau ledakan hama serta resistensi hama. Oleh karena itu, untuk mendukung pengendalian hama yang berwawasan lingkungan maka perlu dilakukannya pengendalian secara ramah lingkungan.) Salah satu alternatif teknik untuk mengendalikan secara ramah lingkungan yaitu pengendalian hayati yang lebih fokus menggunakan musuh alami hama, atau agen pengendali hayati (Purnomo, 2010). Pengendalian hayati dapat menggunakan predator, patogen, parasitoid maupun kompetitor yang dapat menekan populasi hama agar menurunkan tingkat kerusakan bila dibandingkan jika musuh alami tidak ada. Salah satu jenis patogen serangga adalah cendawan entomopatog (Nik et al., 2017).

Pemanfaatan cendawan entomopatogen berpotensi untuk dikembangkan. Salah satu jenis cendawan entomopatogen yang adalah Metarbizium sp. yang efektif membunuh serangga hama (Nik et al., 2017). Berbagai kelebihan pemanfaatan cendawan entomopatogen dalam pengendalian hama ialah mempunyai kapasitas reproduksi yang tinggi, siklus hidupnya pendek, dapat 
membentuk spora yang tahan lama di alam walaupun dalam kondisi yang tidak menguntungkan, relatif aman, bersifat selektif, relatif mudah diproduksi, dan sangat kecil kemungkinan terjadi resisten (Prayogo et al., 2005).

Cendawan Metarbizium sp. dilaporkan dapat diproduksi secara massal dan diformulasikan sebagai bioinsektisida baik dalam bentuk padat maupun cair. Metarbizium sp. dapat diproduksi secara massal pada media instan, seperti SDB (Saborroud Dextrose Broth) atau SDA (Saborroud Dextrose Agar) (Prayogo et al., 2005). Dalam memproduksi

Selain substrat untuk memproduksi cendawan, bahan pembawa (carrier) untuk pembuatan formula bioinsektisida juga berperan dalam mempertahankan keefektifannya bila telah berfungsi sebagai bahan aktif bioinsektisida, tepung jagung dan tepung beras, baik digunakan dalam pembuatan formula bioinsektisida. Selain itu tepung, abu atau tanah liat dapat juga digunakan sebagai bahan pembawa formulasi bioinsektisida.

$\begin{array}{lcr} & \text { Menurut Prayogo et al., (2005) } \\ \text { untuk } & \text { meningkatkan } & \text { keefektifan } \\ \text { cendawan } & \text { entomopatogen dapat }\end{array}$ dilakukan dengan memperhatikan waktu aplikasi, media bahan pembawa, penambahan perekat, tempat penyimpanan dan umur simpan. Penurunan kualitas spora cendawan entomopatogen dapat disebabkan karena berkurangnya sumber karbon, khitin, pati, dan protein pada media perbanyakan. Hasil penelitian Nuryanti et al., (2013) menunjukkan bahwa cendawan $B$. bassiana yang ditumbuhkan pada media beras dengan penambahan tepung belalang atau tepung dedak, mampu menyebabkan mortalitas walang sangit sebesar $78 \%$ dan $71 \%$.

Penelitian tentang penambahan beberapa macam tepung serangga ke dalam media perbanyakan cendawan Metarbizium sp. guna meningkatkan virulensinya belum pernah dilaporkan sebelumnya, sehingga berdasarkan hal tersebut perlu dilakukan penelitian penambahan beberapa jenis tepung serangga pada media perbanyakan. Penelitian ini diharapkan dapat menemukan jenis tepung serangga yang dapat meningkatkan virulensi cendawan Metarbizium sp.

Tujuan penelitian ini adalah untuk mengetahui pengaruh penambahan tepung serangga pada media jagung untuk perbanyakan cendawan Metarbizium sp terhadap mortalitas dan waktu kematian 50\% $\left(\mathrm{LT}_{50}\right)$ hama belalang.

\section{METODE PENELITIAN}

\section{Waktu dan Tempat.}

Penelitian ini dilakukan di Pusat Studi dan Pengembangan Plasma nutfah Pandanwangi, BALITHI (Balai Penelitian Tanaman Hias) Segunung, dan Fakultas Sains Terapan Universitas Suryakancana Cianjur, yang beralamatkan di Kp Sedong, Kecamatan Cianjur, Kabupaten Cianjur pada bulan Maret-April 2019.

\section{Persiapan Isolat Metarhizium sp.}

Biakan murni Metarbizium sp diperoleh dari Satuan Pelayanan Balai Perlindungan Tanaman Pangan dan Hortikultura Wilayah I Cianjur. Sebelum digunakan terlebih dahulu dilakukan isolasi dan perbanyakan terhadap cendawan Metarbizium sp pada media PDA di laboratorium. Setelah diperoleh biakan Metarbizium sp., selanjutnya ditumbuhkan pada media tepung jagung. Hasil biakan ini digunakan sebagai starter.

Proses pembuatan starter yaitu : tepung jagung ditimbang, dimasukkan ke dalam kantong plastik tahan panas masing-masing 100 gram. Selanjutnya jagung dalam kantung plastik tersebut disterilkan pada autoclave dengan temperatur $121{ }^{\circ} \mathrm{C}$, tekanan 15 psi dan dikonstankan selama \pm 2 jam, lalu diangkat dan didinginkan. Pada media tepung jagung yang steril tersebut dilakukan inokulasi isolat murni Metarbizium sp. dengan menggunakan jarum ose steril. Selanjutnya plastik dikocok agar spora 
cendawan dapat tersebar merata pada media jagung, kemudian diinkubasikan pada suhu kamar selama \pm 2 minggu. Perbanyakan massal Metarbizium sp. dilakukan dengan proses yang sama seperti pembuatan starter, hanya tidak menggunakan inokulasi isolat murni melainkan menggunakan starter inokulum dengan perbandingan satu bagian starter untuk 5 bagian media perbanyakan. Media perbanyakan yang digunakan ada 3 macam yaitu: (P1 media perbanyakan tepung jagung ditambah $15 \%$ tepung jangkrik, (P2) media perbanyakan tepung jagung ditambah 15\% tepung kroto, (P3) media perbanyakan tepung jagung saja.

\section{Persiapan Serangga Uji}

Belalang kembara sebagai serangga uji diperoleh dari lahan budidaya padi di lahan padi Pandanwangi Kabupaten Cianjur, kemudian dipelihara dalam kandang pemeliharaan yang telah berisi tanaman padi.

\section{Persiapan Tanaman Padi}

Mempersiapkan bibit padi untuk pakan belalang dimana benih padi di semai dalam pot yang telah terisi tanah yang kemudian bibit padi digunakan untuk proses aplikasi.

\section{Penghitungan Jumlah Konidia}

Untuk mengetahui pengaruh teknik perbanyakan dengan penambahan beberapa bahan terhadap jumlah konidia cendawan Metarhizium sp, maka dilakukan pengitungan jumlah spora. Penghitungan jumlah konidia dilakukan dengan beberapa langkah. Langkah pertama adalah cendawan entomopatogen dari masing-masing teknik perbanyakan ditimbang sebanyak 1 gram. Lalu cendawan yang telah ditimbang tersebut dicampur aquades sebanyak $100 \mathrm{ml}$ kemudian dihancurkan/dilumatkan, lalu disaring sehingga didapat suspensi konidia cendawan. Langkah selanjutnya yaitu, ruang hitung ditutup dengan kaca obyek dan diteteskan suspensi sebanyak 1 cc dengan pipet tetes, sehingga suspensi mengalir ke bawah kaca obyek dan ruang hitungpun dapat terisi. Terakhir jumlah konidia dihitung dalam lima kotak besar dan 16 kotak pengecil yang masingmasing dilakukan di bawah mikroskop, penghitungan diulang 2 kali. Jumlah konidia dicatat dan dihitung dengan rumus:

$v=\frac{j}{n x t}$

Keterangan:

$\mathrm{v}=$ volume

$\mathrm{j}=$ jumlah konidia

$\mathrm{n}=$ jumlah kotak besar

$\mathrm{t}=$ jumlah kotak pengecil

\section{Pembuatan Larutan Insektisida Hayati}

Larutan insektisida hayati dibuat dengan cara mengambil 10 gram media biakan yang telah ditumbuhi Metarbizium sp. dilumatkan lalu campurkan ke dalam $200 \mathrm{ml}$ aquades, kemudian diaduk hingga rata dengan menggunakan rotamixer. Selanjutnya campuran tersebut disaring untuk diaplikasikan dalam pengujian.

\section{Aplikasi}

Insektisida hayati sebanyak 10 gram cendawan Metarbizium sp. dengan kerapatan konidia disetiap perlakuan yaitu: tepung jagung + tepung jangkrik $5.2 \mathrm{x}$ $10^{6}$, tepung jagung + tepung kroto $4.7 \mathrm{x}$ $10^{6}$, dan tepung jagung $4.35 \times 10^{6}$, dilakukan dalam air dan diaduk rata untuk memperoleh nilai Mortalitas, dan mengetahui tingkat virulensi cendawan Metarbizium sp. dalam media tepung yang dihitung pada 12 jam selama 8 hari. Teknik aplikasi yang digunakan yaitu metode kontak (pada metode ini serangga uji disemprot berbagai konsentrasi insektisida hayati).

\section{Rancangan Percobaan}

Penelitian ini adalah penelitian eksperimental dengan menggunakan Rancangan Acak Lengkap (RAL) yang terdiri dari 3 perlakuan yaitu:

1. Tepung jagung 100 gram+tepung jangkrik 15\%, 
2. Tepung jagung 100 gram+tepung kroto $15 \%$,

3. Tepung jagung 100 gram.

Masing masing perlakuan sudah ditumbuhi cendawan Metarbizium sp., dengan umur biakan 14 hari. Setiap perlakuan dilakukan 5 kali ulangan. Penelitian ini menggunakan metode kontak (serangga uji disemprot berbagai konsentrasi insektisida hayati). Setiap percobaan menggunakan serangga uji belalang kembara berjumlah 3 ekor.

Adapun tahap uji penambahan tepung serangga pada media perbanyakan terhadap virulensi Metarhizium sp. yaitu sebagai berikut:

1. Menyiapkan botol aqua kemudian menempelkan kertas label yang telah diberikan kode setiap perlakuan dan ulangan kebagian tengah aqua selanjutnya memasukkan bibit padi Pandanwangi. Penggunaan botol aqua dimaksudkan untuk mempermudah pengontrolan setelah pengaplikasian.

2. Membuat larutan insektisida hayati dalam gelas ukur dengan cara mengambil 10 gram media biakan yang telah ditumbuhi Metarbizium sp. dilumatkan lalu campurkan ke dalam $200 \mathrm{ml}$ aquades, kemudian diaduk hingga rata dengan menggunakan rotamixer. Selanjutnya campuran tersebut disaring untuk diaplikasikan dalam pengujian.

3. Mengumpulkan serangga uji dari tempat pemeliharaan dengan menggunakan tangan.

4. Memasukkan serangga uji ke dalam botol aqua yang berisikan bibit padi Pandanwangi dengan 3 serangga uji /botol dan setiap botol dilubangi bagian tengahnya menggunakan kawat panas untuk memastikan serangga uji mendapatkan udara untuk bernapas dan setiap lubang berukuran kecil yang berjumlah lebih dari 5 lubang perbotolnya.
5. Melakukan pengamatan terhadap perilaku belalang setelah aplikasi uji biopestisida.

6. Mencatat jumlah serangga uji yang mati pada setiap perlakuan pencatatan dilakukan pada 12 jam, 24 jam, 36 jam, 48 jam, 60 jam, 72 jam, 84 jam, 96 jam, 108 jam, 120 jam, 132 jam, 144 jam, 156 jam, 168 jam, 180 jam, 192 jam.

\section{Teknik Pengumpulan Data}

Pengamatan dilakukan setiap 12 jam selama 8 hari setelah aplikasi. Pengamatan meliputi mortalitas serangga uji, dan waktu kematian 50\% (LT ${ }_{50}$ ), yaitu

1. Mortalitas

Persentase mortalitas serangga uji dihitung dengan menggunakan rumus (Susilo et al., 1993), yaitu:

$$
\mathrm{P}=\mathrm{A} / \mathrm{B} \times 100 \% \text {, }
$$

Keterangan:

$\mathrm{P}=$ Persentase kematian serangga uji

$\mathrm{A}=$ jumlah serangga uji mati pada setiap perlakuan

$\mathrm{B}=$ jumlah serangga uji awal pada setiap perlakuan.

2. Waktu kematian 50\% (Lethal Time 50\% / $\mathrm{LT}_{50}$ )

Penentuan LT $_{50}$ dilakukan untuk mengetahui berapa waktu yang dibutuhkan untuk mengakibatkan kematian hama sebanyak 50\% dengan menggunakan probit analisys.

\section{Teknik Analisis Data}

Data yang diperoleh diolah menggunakan bantuan software microsoft excel, dan Minitab. Data yang diperoleh dari pengamatan mortalitas dilakukan dengan sidik ragam (ANOVA) jika terdapat pengaruh dilakukan uji lanjut TUKEY dengan taraf kepercayaan 95\% atau a 5\% pada program Minitab dan uji lanjut regresi pada program software microsoft excel. Nilai $\mathrm{LT}_{50}$ di analisis dengan menggunakan probit analisis pada program software microsoft excel. 


\section{HASIL DAN PEMBAHASAN}

\section{Mortalitas Belalang Kembara (Locusta migratoria)}

Pengamatan persentase kematian belalang kembara pada uji patogenesitas cendawam Metarbizium sp. dilakukan setiap 12 jam selama 8 hari setelah aplikasi. Hasil analisis sidik ragam terhadap persentase kematian belalang kembara dengan menggunakan tiga perlakuan berbagai konsentrasi larutan insektisida hayati cendawan Metarbizium sp. dapat dilihat pada tabel 1.

Tabel 1. Rata-rata Mortalitas (\%) Belalang.

\begin{tabular}{lcccc}
\hline \multirow{2}{*}{ Perlakuan } & \multicolumn{4}{c}{ Waktu pengamatan (jam) } \\
\cline { 2 - 5 } & $\mathbf{7 2}$ & $\mathbf{8 4}$ & $\mathbf{9 6}$ & $\mathbf{1 0 8}$ \\
\hline P1 & $67 \mathrm{a}$ & $33 \mathrm{a}$ & $0 \mathrm{a}$ & $0 \mathrm{a}$ \\
P2 & $53 \mathrm{ab}$ & $47 \mathrm{a}$ & $0 \mathrm{a}$ & $0 \mathrm{ab}$ \\
P3 & $0 \mathrm{bc}$ & $0 \mathrm{a}$ & $40 \mathrm{a}$ & $60 \mathrm{c}$ \\
\hline
\end{tabular}

Keterangan: P1 : Tepung jagung 100 gram+tepung jangkrik 15\% ; P2 : Tepung jagung 100 gram+tepung kroto $15 \%$; P3 : Tepung jagung 100 gram

Tabel 1 menunjukkan beberapa konsentrasi larutan insektisida hayati cendawan Metarbizium sp. memberikan pengaruh terhadap mortalitas belalang. Hasil pengamatan pada 72 jam setelah aplikasi, bioinsektisida dengan media atau Perlakuan 1 (Tepung jagung 100 gram+tepung jangkrik 15\%) menunjukkan kematian serangga uji $67 \%$, dan perlakuan 2 (Tepung jagung 100 gram+tepung kroto 15\%) kematian serangga uji 53\% (8 serangga uji) namun perlakuan 3 (Tepung jagung 100 gram) belum terlihat memberikan dampak terhadap mortalitas belalang kembara. Hasil penelitian Herlinda et al., (2006) menunjukkan penambahan bahan yang mengandung khitin dan protein seperti tepung jangkrik pada media biakan dapat merangsang cendawan entomopatogen menghasilkan enzim khitinase. Samsinakova et al., (1971) melaporkan cendawan entomopatogen menghasilkan enzim khitinase yang mampu mendegradasi khitin pada kutikula serangga. Dengan demikian, peningkatan kemampuan Metarbizium sp. membunuh belalang kembara disebabkan adanya peningkatan enzim khitinase yang mendegradasi kutikula dan kitin serangga uji pada proses infeksi belalang kembara.

Pengamatan 84 jam setelah aplikasi beberapa konsentrasi larutan insektisida hayati cendawan Metarbizium sp. didapatkan perlakuan terbaik yaitu pada perlakuan 1 (Tepung jagung 100 gram+tepung jangkrik 15\%) dengan kematian serangga uji 33\%, dan perlakuan 2 (Tepung jagung 100 gram + tepung kroto 15\%) dengan kematian serangga uji $47 \%$ namun perlakuan 3 (Tepung jagung 100 gram) belum terlihat memberikan dampak terhadap mortalitas belalang kembara. (gambar 1) 


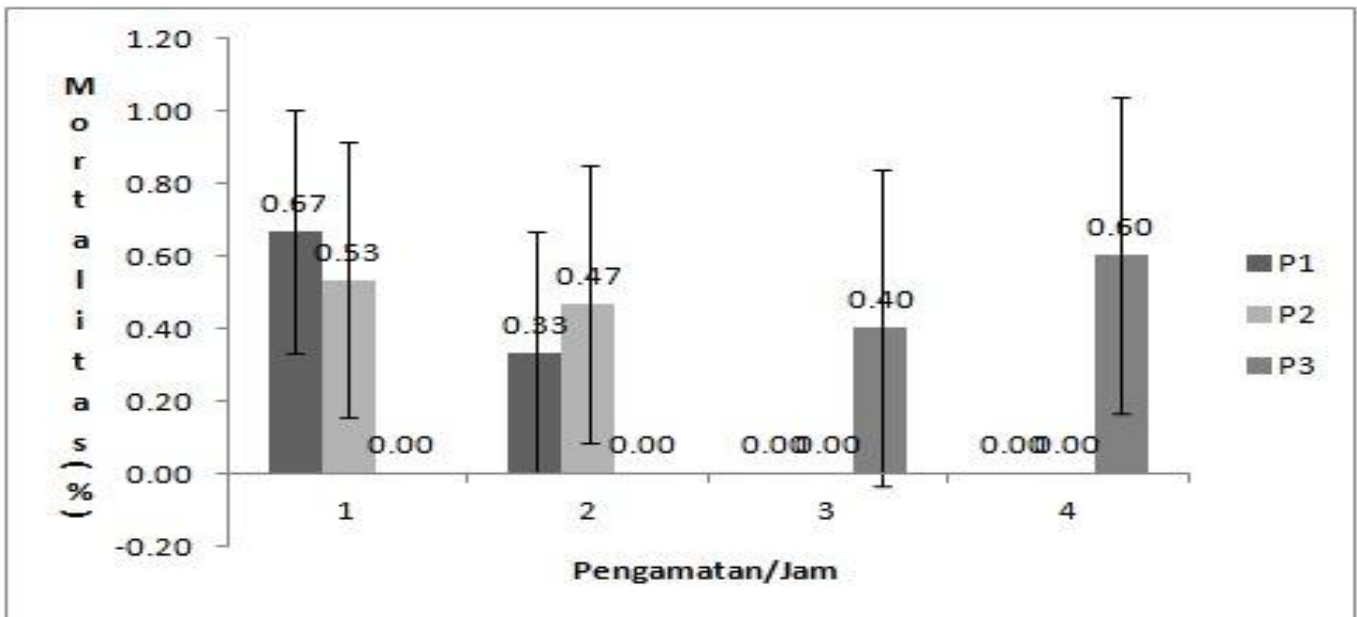

Gambar 1 Grafik mortalitas belalang setelah aplikasi bioinsektisida Metarbiæium sp. selama 72, 84, 96, dan 108 jam pengamatan.

Pengamatan 96 jam setelah aplikasi beberapa konsentrasi larutan insektisida hayati cendawan Metarbizium sp. dimana perlakuan 3 (Tepung jagung 100 gram) terlihat baru memberikan dampak terhadap mortalitas serangga uji yaitu sebanyak 40\%, sedangkan untuk perlakuan 1 dan 2 seluruh serangga uji telah mati. Menurut Prayogo et al., (2005) jaringan dan cairan tubuh serangga yang terserang cendawan entomopatogen biasanya akan habis diserap oleh cendawan sehingga serangga mengalami kematian. Pengamatan 108 jam setelah aplikasi beberapa konsentrasi larutan insektisida hayati cendawan Metarbizium sp. dimana perlakuan 3 (Tepung jagung 100 gram) dengan kematian serangga uji $60 \%$.

Selanjutnya dilakukan pengujian lebih lanjut menggunakan analisis regresi untuk melihat pengaruh jenis tepung serangga terhadap kematian belalang kembara. Hasil pengamatan 72 jam setelah aplikasi perlakuan didapatkan nilai koefisien determinasi (R-Square) adalah 0,82 , hal ini berarti jenis tepung serangga memberikan pengaruh sebanyak $82 \%$ terhadap kematian belalang kembara, pada pengamatan 84 jam setelah aplikasi perlakuan didapatkan nilai koefisien determinasi (R-Square) adalah 0,36, hal ini berarti jenis tepung serangga tidak terlalu memberikan pengaruh dikarenakan kematian hanya 36\% terhadap kematian belalang kembara, pengamatan 96 jam setelah aplikasi perlakuan didapatkan nilai koefisien determinasi (R-Square) adalah 0,65 , hal ini berarti jenis tepung serangga tidak terlalu memberikan pengaruh dikarenakan kematian hanya 65\% terhadap kematian belalang kembara, dan pada untuk pengamatan 108 jam setelah aplikasi perlakuan didapatkan nilai koefisien determinasi (R-Square) adalah 0,65 , hal ini berarti jenis tepung serangga tidak terlalu memberikan pengaruh dikarenakan kematian hanya 65\% terhadap kematian belalang kembara.

Menurut Nuryanti et al., (2013), dalam penelitianya bahwa penambahan media tepung serangga sangat berpengaruh terhadap virulensi cendawan B.bassiana untuk mematikan walang sangit. Belalang kembara yang terinfeksi Metarbizium sp. menunjukkan gejala berkurangnya aktivitas gerak dan makan, selanjutnya belalang terjatuh ke dasar botol aqua meskipun belum mengalami kematian. Beberapa waktu kemudian belalang mengalami kematian ditandai dengan tubuhnya yang kaku dan warna tubuhnya menjadi kusam. Untuk memastikan bahwa kematian karena terifeksi Metarbizium sp., maka tubuh belalang yang telah mati diletakkan di tempat yang lembab yaitu di atas tisu yang telah sedikit dibasahi. Menurut 
Sheroze et al., (2003) bahwa kelembaban relatif $80 \%$ dan suhu $30^{\circ} \mathrm{C}$ merupakan kondisi yang baik untuk pertumbuhan cendawan entomopatogen Metarhizium. Keesokan harinya terlihat tubuh belalang kembara yang mati karena terinfesi Metarbizium sp. ditumbuhi oleh hifa cendawan Metarbizium sp. yang berwarna hijau, seperti pada gambar 2 .

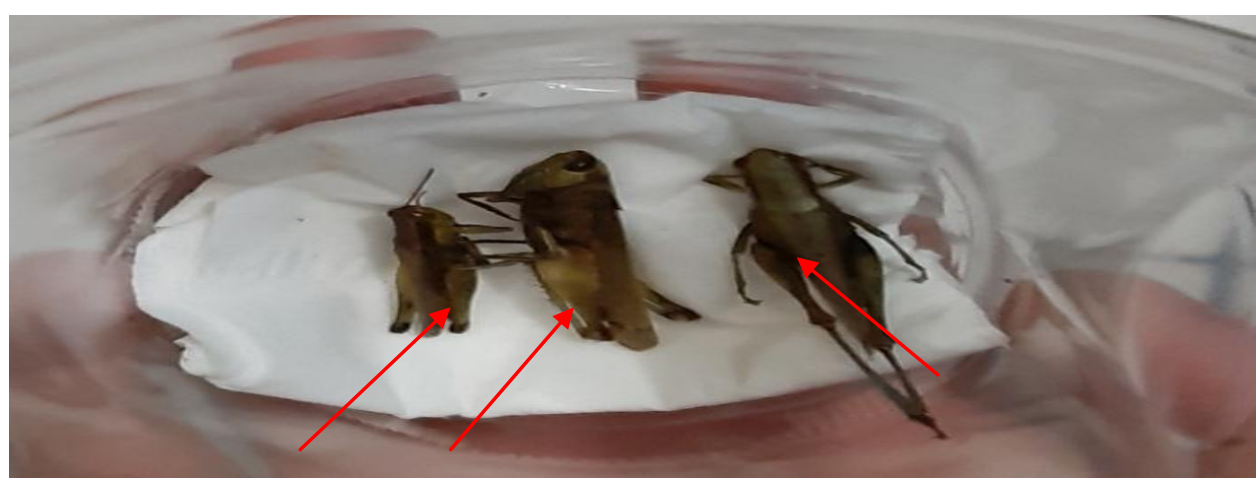

Gambar 2 Belalang yang terinfeksi Metarbiżium sp.

Pada awalnya pertumbuhan hifa cendawan terutama pada bagian lipatan kutikula antar ruas tubuh, selanjutnya hifa berkembang ke permukaan tubuh belalang dan berkembang biak di dalam tubuh belalang hingga dapat menyebabkan kematian pada belalang.

Menurut Susilo et al., (1993), mekanisme infeksi cendawan Metarbizium sp diawali dengan invasi, yaitu masuknya patogen ke dalam tubuh serangga inang. Kemudian patogen berkembang biak di dalam tubuh serangga. Invasi mengalami akselerasi dan mencapai klimaks pada puncak infeksi dan berakhir dengan kematian belalang. Apabila invasi terjadi segera setelah inokulasi, maka jangka waktu sejak inokulasi sampai terjadinya kematian serangga dapat ditentukan sebagai periode letal.

\section{Lethal Time $\mathbf{5 0 \%}$}

Pengamatan mortalitas belalang kembara dilanjutkan dengan pengamatan $\mathrm{LT}_{50}$, menggunakan probit analysis pada program software microsoft excel. Lethal time $50 \%$ dilakukan untuk mengetahui berapa waktu yang dibutuhkan untuk mengakibatkan kematian hama sebanyak $50 \%$. Hasil analisis LT $_{50}$ di dapat berbagai nilai estimase atau nilai rata-rata kematian pada masing-masing perlakuan, maka dapat dilihat pada tabel 2.

Tabel 2 Hasil uji probit analysis efektivitas insektisida hayati Metarbizium sp. terhadap mortalitas pada

\begin{tabular}{lll}
\multicolumn{1}{c}{ LT $_{50 .}$} & \\
\hline Perlakuan. & Jumlah Konidia & LT $_{50}$ (Jam) \\
\hline P1 & $5,2 \times 10^{6}$ & 72 \\
P2 & $4,7 \times 10^{6}$ & 72 \\
P3 & $4,35 \times 10^{6}$ & 108 \\
\hline
\end{tabular}

Keterangan: P1 : Tepung jagung 100 gram+tepung jangkrik 15\% ; P2 : Tepung jagung 100 gram+tepung kroto $15 \%$; P3 : Tepung jagung 100 gram

Berdasarkan hasil uji probit analysis tabel 2 perlakuan 1 (Tepung jagung 100 gram+tepung jangkrik 15\%) berada pada angka 72 yang berarti bahwa kematian $67 \%$ belalang kembara berada pada waktu pengamatan 72 jam setelah aplikasi, dan perlakuan 2 (Tepung jagung 100 gram+tepung kroto $15 \%$ ) berada pada angka 72 yang berarti bahwa kematian $53 \%$ belalang kembara berada pada waktu pengematan 72 jam setelah aplikasi, sedangkan pada perlakuan 3 (Tepung jagung 100) berada pada angka 108 yang berarti bahwa kematian 60\% belalang kembara berada pada waktu pengamatan 108 jam setelah aplikasi. Menurut Juliani 
(2017), semakin kecil nilai LT maka semakin efektif suatu insektisida yang digunakan. Sehingga semakin singkat pula waktu yang dibutuhkan untuk mengendalikan belalang kembara sebanyak 50\%. Pada hasil penelitian Herlinda et al., (2008), formulasi b dengan $10^{7}$ spora Metarbizium sp. per $\mathrm{ml}, \mathrm{LT}_{50}$ dalam mengendalikan wereng punggung putih diperoleh pada hari ke 2,99.

Kecepatan cendawan Metarbizium sp. mematikan belalang kembara dipengaruhi kerapatan konidia yang berkecambah pada integumen serangga. Semakin banyak konidia yang berkecambah pada integumen serangga akan mengakibatkan integumen lebih cepat rusak dan cairan tubuh akan lebih cepat habis yang mengakibatkan serangga semakin cepat mati. Menurut Prayogo et al., (2005) jaringan dan cairan tubuh serangga yang terserang cendawan entomopatogen biasanya akan habis diserap oleh cendawan, sehingga serangga mati.

Penghitungan jumlah spora yang dilakukan dalam penelitan ini menghasilkan kerapatan konidia dari setiap perlakuan larutan insektisida hayati cendawan entomopatogen Metarbizium sp. yaitu perlakuan pertama (tepung jagung 100 gram+tepung jangkrik 15\%) dengan kerapatan konidia $5.2 \times 10^{6}$, perlakuan ke 2 (tepung jagung 100 gram+tepung kroto 15\%), dengan kerapatan konidia $4.7 \times 10^{6}$, dan perlakuan ke 3 (tepung jagung 100 gram) dengan kerapatan konidia $4.35 \mathrm{x}$ 106. Menurut Prayogo et al., 2005, kecepatan cendawan Metarbizium sp. mematikan serangga juga dipengaruhi kerapatan konidia yang berkecambah pada integumen serangga. Semakin banyak konidia yang berkecambah pada integumen serangga, maka dapat mengakibatkan integumen lebih cepat rusak dan cairan tubuh akan lebih cepat habis yang mengakibatkan serangga semakin cepat mati.

\section{KESIMPULAN}

Berdasarkan penelitian uji penambahan tepung serangga pada media perbanyakan terhadap virulensi Metarbizium sp. pada belalang kembara yang telah dilakukan menunjukkan hasil sebagai berikut.

1. Penambahan tepung jangkrik dan tepung kroto pada media tepung jagung untuk perbanyakan cendawan Metarbizium sp. meningkatkan mortalitas belalang kembara

2. Penambahan tepung jangkrik dan tepung kroto pada media tepung jagung untuk perbanyakan cendawan Metarbizium sp. menurunkan nilai $\mathrm{LT}_{50}$.

\section{DAFTAR PUSTAKA}

Herlinda, S., Hartono, H., \& Irsan, C. 2008. Efikasi Bioinsektisida Formulasi Cair Berbahan Aktif Beauveria bassiana (Bals.) Vuill. dan Metarhizium sp. pada Wereng Punggung Putih (Sogatella furcifera Horv.). J. Eprints. Unsri.

Herlinda S, Muhamad DU, Yulia P \& Suwandi. 2006. Kerapatan dan Viabilitas Spora Beauveria Bassiana Akibat Subkultur dan Pengayaan Media Serta Virulensinya Terhadap Larva Plutella Xylostella (Linn.). JHPT. Tropika. 6 (2) : 70-78.

Juliani, W. 2017. Efektivitas Ekstrak Daun Kipahit (Tithonia diversifolia) dan Daun Salaria (Scotinophara coarctata) pada Padi Pandanwangi. Skripsi. Fakultas Sains Terapan Universitas Suryakancana. Cianjur.

Kartohardjono, Arifin, Denan Kertoseputro, and Tatang Suryana. 2009. Hama padi potensial dan pengendaliannya. J. Balai Besar Penelitian Tanaman Padi. Bogor.

MP3C Beras Pandanwangi Cianjur. Cianjur: Masyarakat Pelestari Padi Pandanwangi Cianjur.

Nik, N., Rusae, A., dan Atini, B. 2017. Identifikasi Hama dan Aplikasi 
Bioinsektisida pada Belalang Kembara (Locusta migratoria L) sebagai Model Pengendalian Hama Terpadu pada Tanaman Sorgum. J. Savana Cendana 2(3) 46-47.

Nuryanti, N. S. P., Wibowo, L., \& Azis, A. 2013. Penambahan Beberapa Jenis Bahan Nutrisi pada Media Perbanyakan untuk Meningkatkan Virulensi Beauveria bassiana terhadap Hama Walang Sangit. Jurnal Hama dan Penyakit Tumbuban Tropika, 12(1): 64-70.

Pamili, A. 2014. Populasi Belalang dan Warna Daun Jagung pada Pemupukan yang Berbeda. Diss. Universitas negeri gorontalo.

Prayogo Y, Tengkano W \& Marwoto. 2005. Prospek Cendawan Entomopatogen Metarhizium anisopliae untuk Mengendalikan Ulat Grayak Spodoptera Litura pada Kedelai. J. Litbang. Pertanian 24:1926.

Purnomo, H. 2010. Pengantar Pengendalian Hayati. C. V. Andi Offset. Yogyakarta.

Samsinakova, A., Misikova S \& Leopold, J. 1971. Action of Enzymatic System of Beauveria bassiana on cuticle of The Greater Way Moth Larvae (Galleria mellonella). J. Invert. Pathol. 18:322-330

Sembiring. S. A. 2013. Sistem Pakar Diagnosa Penyakit dan Hama Tanaman Padi. Jurnal Pelita Informatika Budi Darma (9). STMIK Budi Darma. Medan.

Sheroze, A., Rashid, A., Shakir, A. S., \& Khan, S. M. 2003. Effect of BioControl Agents on Leaf Rust of
Wheat and Influence of Different Temperature and Humidity Levels on Their Colony Growth. International Journal of Agriculture \& Biology, 5(1), 83-85.

Susilo FX, Hasibuan R, Nordin GL \& Brown GC. 1993. The Concept of Threshold Density in Insect Pathology: A Theoretical and experimental study on Tetranychus - Neozygites Mycosis. Prosiding Makalah Simposium Patologi Serangga I. Yogyakarta, 12-13 Oktober 1993. 